УДК 398.332.12 (477.85)

\author{
Козек Микола Іванович, \\ аспірант, \\ Київський національного \\ університет культури і мистецітв, \\ Киів, Україна \\ kozekozekozekozekozekozekozek1@gmail.com
}

\title{
ВЕЛИКОДНІ СВЯТА НА БУКОВИНСЬКІЙ ГУЦУЛЬЩИНІ ТРАДИЦІї ТА ОБРЯДИ
}

Мета роботи виявити регіональні особливості пасхальних свят на буковинській Гуцульщині, притаманних українцям Гуцульщини початку XX ст. i до нині. Методи дослідження: аналіз наукових етнографічних праць дослідників буковинської Гуцульщини та грунтується на зборі матеріалу польових експедицій з гуцульських сіл, що дає можливість віднайти нові традиції та обряди українців, проаналізувати їх видозмінність із початку XX ст. до сьогодення. Основні методи дослідження, що використані в роботі: аналітичний, описовий, порівняльний. Наукова новизна полягає в тому, що вперше досліджені та зібранні матеріали про регіональні особливості пасхальних свят та обрядів у селах Стебні, Розтоки, Усть-Путила буковинської Гуцульщини. Це дослідження дозволить відродити цілісну обрядову дію святкування українців від Вербної неділі до Провідної неділі, а також надасть можливість знайти спільні та відмінні риси в святкуванні 3 ін. селами буковинської Гуцульщини. Осягнути їх первісну сутність та етапи розвитку. Висновки: Аналізуючи та досліджуючи пасхальну обрядовість в селах Стебні, Розтоки, Усть-Путила, Путильського району буковинської Гуцульщини, було виявлено регіональні особливості в святкуванні великодніх свят притаманних тільки гуцулам буковинського краю. До головних особливостей, які характерні для буковинської Гуцульщини, належать: обрядова дія з вербою на Вербну неділю, ставлення гуцулів до вогню в чистий четвер, особливим вшануванням предків під час всього святкування великодніх свят та обрядові дії дітвори, які ходили за писанками в понеділок після Великодня.

Ключові слова: Вербна неділя, Великдень, Проводи, кошик, гаївки, календарні свята, традиція, обряд, поминальна неділя.

Козек Николай Иванович аспирант, Киевский национальний университет культуры и искусств, Киев, Украина

Пасхальные праздники на буковинской Гуцульщине: традиции и обряды

Цель работы Выявить региональные особенности пасхальных праздников на буковинской Гуцульщине, присущих украинской Гуцульщины начала XX в. по сей день. Методы исследования включают в себя анализ научных этнографических работ исследователей буковинской Гуцульщины и основывается на сборе материала полевых экспедиций с гуцульских деревень, что дает возможность найти новые традиции и обряды украинцев, 
проанализировать их видозминнисть с начала XX в. до современности. Основные методы исследования, использованные в работе: аналитический, описательный, сравнительный. Научная новизна заключается в том, что впервые комплексно собраны и исследованы региональные особенности пасхальных праздников и обрядов в селах Стебни, Розтоки, Усть-Путила буковинской Гуцульщины. Исследование которых позволит возродить целостное обрядовое действие празднования украинский праздников от Вербного воскресенья до Пасхи, понять их первоначальную сущность и этапы развития. Выводы: Анализируя и исследуя пасхальную обрядность в селах Стебни, Розтоки, Усть-Путила, Путильского района буковинской Гуцульщины, было обнаружено региональные особенности в праздновании Пасхи присущих только гуцулам буковинского края. К главным особенностям характерных на буковинской Гуцульщине можно отнести: обрядовое действие с ивой на Вербное воскресенье, отношение гуцулов к огню в чистый четверг, особым почитанием предков во время всего празднования Пасхи и походы детворы за пасхальными яйцами в понедельник после Пасхи.

Ключевые слова: Вербное воскресенье, Пасха, Проводы, корзина, гаевки, календарные праздники, традиция, обряд, поминальное воскресенье.

Kozek Mykola, postgraduate, Kyiv National University of Culture and Arts, Kyiv, Ukraine

Easter holidays in Bukovynian Hutsulshchyna: traditions and rituals

The purpose of the article is to reveal regional peculiarities of Easter holidays in Bukovynian Hutsulshchyna, which are celebrated by Ukrainians of Hutsulshchyna to the present day. The research methodology consisted in the analysis of ethnographic researches on Bukovynian Hutsulshchyna and was based on collecting materials during field expeditions in Hutsul villages, which allowed for finding new traditions and rituals of Ukrainians and analyzing their modifications from the beginning of the 20th century to the present day. The main research methods included the analytical, descriptive and comparative methods. The scientific novelty of the work lies in the first attempt to provide a complex study of regional peculiarities of Easter holidays and rituals in the villages of Stebni, Roztoky, Ust-Putyla in Bukovynian Hutsulshchyna. This study will help to revive the entire ritual action of Ukrainian celebrations from Yew Sunday to Farewell Sunday, to understand their essence and stages of development. Conclusions. As a result of the analysis of Easter rituals in the villages of Stebni, Roztoky and Ust-Putyla, Putyla district, Bukovynian Hutsulshchyna, regional features concerning Easter celebrations which are only peculiar to Hutsuls of Bukovyna region were revealed. The main features of Bukovynian Hutsulshchyna include ceremonial action involving pussy willow on Yew Sunday, the attitude of Hutsuls to fire on Chare Thursday, special worship of the ancestors during the whole celebration of Easter holidays and children's rituals involving Easter eggs on Monday after Easter.

Key words: Yew Sunday, Farewell, Easter basket, haivkas, calendar holidays, tradition, ritual, Remembrance Sunday. 
Вступ. Постановка наукової проблеми та ¥іi значення: в умовах урбанізаційних процесів з часів XX ст. і до наших днів гуцульське суспільство має багато традицій, звичаїв та обрядів, які мали позитивний моральновиховний зміст, але сьогодні втратили своє значення частково або повністю.

Глобалізаційні процеси та поширення «масової культури» призводять до трансформації народного календаря буковинських гуцулів, тож сьогодні особливо актуальним є збереження традиційної календарної обрядовості, бо саме ці обряди та звичаї є свідками історичного минулого гуцулів.

На занепад переважної бульшості давніх звичаїв та обрядів буковинської Гуцульщини негативно вплинули румунські загарбники в першій пол. ХХ ст., а пізніше радянська влада, а вже, коли Україна стала незалежною, то, на жаль, немає комплексних наукових досліджень про традиційну обрядовість буковинської Гуцульщини.

Комплексний збір та дослідження історичної етнографічної інформації про святкову обрядовість буковинської Гуцульщини надасть можливість не тільки відродити цілісну календарно-обрядову історію буковинських гуцулів осягнувши іiі первісний сенс, генетичні витоки та етапи розвитку, а й виявити характерні відмінності в святкових обрядових діях, притаманних тим чи іншим селам буковинської Гуцульщини.

Збереження та відновлення календарних свят та обрядів $є$ особливо актуальним не тільки для гуцулів, які втрачають свій, століттями набутий, духовний світ, а й для України в цілому, в якій Гуцульщина виступає як самобутній, неповторний, етнічний, культурний край.

Мета статті - виявити регіональні особливості пасхальних свят на буковинській Гуцульщині, притаманних українцям Гуцульщини початку ХХ ст. й до нині.

Виклад основного матеріалу народні свята весняного циклу на буковинській Гуцульщині та Гуцульщині загалом, формують порядок ведення господарства українців пов'язаного, насамперед, із скотарством, яке в гуцулів є основним заняттям і сьогодні.

Календарні звичаї буковинської Гуцульщини не просто формують загальну культурну спадщину Гуцульщини в цілому, а в своїх обрядових діях демонструють видозмінність у самобутності населення, яке проживає по інший бік Черемоша. Особливо ця відмінність проявися із запровадженням на Гуцульщині християнства, так, на івано-франківській Гуцульщині, переважають католицькі церкви, а на буковинській православні, це звичайно, не могло не вплинути на історичні особливості етнічної свідомості буковинських гуцулів.

Так для прикладу можемо подати навіть специфіку вітання гуцулів при зустрічі. Івано-Франківські гуцули при зустрічі кажуть: «Слава Ісусу Христу», а відповідають: «Навіки слава», на буковинській Гуцульщині, старі гуцули вітаються: «А дужі?», відповідають: «Гараздик ви собі?».

Проте, так вже історично склалося, що етнографи Гуцульщини в основному досліджували Івано-Франківську та Закарпатську Гуцульщину, не приділяючи достатньої уваги буковинській Гуцульщині. 
Аналіз останніх досліджень і публікацій 3 цієї проблеми: календарну обрядовість та трансформаційні зміни в обрядовості буковинської Гуцульщини свого часу досліджували такі відомі етнографічні науковці як: С. Килимник, Я. Музиченко, Я. Самотіс, Г. Кожолянко, Р. Ф. Кайндль, І. Сеньків та ін. Вони аналізували календарну обрядовість буковинських гуцулів у порівнянні з розвитком інших, як гірських, так і рівнинних регіонів українських народів.

Кожолянко О. досліджував традиційний народний календар українців Буковини, в своїй роботі «Календарні свята та обряди українців Буковини: семантика i символіка» він застосовує порівняльний метод, порівнюючи обрядовість гуцулів та бойків, спосіб святкування рівнинних українців та гірських. Про те в його дослідженнях практично відсутня інформація про пасхальну обрядовість у селах буковинської Гуцульщини, він описував про народні звичаї та традиції в цілому буковинської Гуцульщини, не акцентуючи увагу на тому, з яких сіл взята інформація. Сеньків I. досліджував традиційну гуцульську обрядовість у контексті Гуцульщини в цілому, він досить широко подає матеріал про цей край в своїй праці «Гуцульська спадщина». Проте, варто зазначити, що в науковій праці автора не йдеться про великодню обрядовість із сіл буковинської Гуцульщини, дослідник описав лише в загальному обрядовість на Гуцульщині. Дослідниця української культурної спадщини Я. Музиченко в науковій праці «Від Романа до Йордана» описує тільки деякі фрагменти обрядових дій на Гуцульщині, які проаналізовані нижче в статті. Дослідник Гуцульщини Хоткевич. Г. в своїй праці «Гуцули й Гуцульщина» дуже стисло подає матеріал про великодню обрядовість на Гуцульщині, він не наводить жодного села з буковинської Гуцульщини, звідки би були хоч якісь дані. Етнограф України Килимник С. в своїй праці «Український рік у народних звичаях в історичному освітленні», як і Хоткевич Г., описує традиційну пасхальну обрядовість в цілому з Гуцульщини. Відомий дослідник Гуцульщини Кайндль Р. Ф. в науковій праці «Гуцули» подає цікавий матеріал про великодню обрядовість на буковинській Гуцульщині, але він наводить відомості про обрядові дії кін. XIX - поч. ХХ ст., в роки своєї творчої діяльності. Найбільше вагомої інформації про великодню обрядовість на буковинській Гуцульщині подає дослідниця Самотіс Я. в своїй статі «Традиційна великодня обрядовість буковинських гуцулів», яка базується на матеріалах польових досліджень буковинського гуцульського краю Путильського та Вижницького районів. Але варто зазначити, що дослідниця збирала матеріал тільки $з$ декількох сіл буковинської Гуцульщини, в Путильському районі: смт. Путила, с. Бісків, с. Гробище, с. Селятин, с. Розтоки, с. Товарниця, у Вижницькому районі: смт. Берегомет, с. Лопушна, с. Віженка, с. Шепіт Долішній.

Однак великодню обрядовість буковинської Гуцульщини, 3 проаналізованих досліджень, не можна вважати достатньо висвітленою та дослідженою в науковій літературі. Про великодню обрядовість в селах Стебні та УстьПутила Путильського району інформація взагалі відсутня, про с. Розтоки цього ж району певна інформація $\epsilon$, але там не висвітлені обрядові дії, які відбуваються у передвеликодній «чистий четвер». Також варто зазначити, що 
в кожному селі буковинської Гуцульщини побутують як спільні, так і відмінні риси в святкуванні великодніх свят, про які й піде мова в нашій статті.

Пасхальні обрядові дії на Гуцульщині різняться від загальноукраїнських великою кількість обрядових дій, пов'язаних із скотарством, збиральництвом та землеробством. Гуцули й сьогодні твердо дотримуються всіх церковних канонів у святкуванні великодніх свят.

Шанобливе ставлення до природи, своїх родичів та домашніх тварин на буковинській Гуцульщині сформувало велику кількість звичаїв, повір’їв та прикмет, які були дослідженні в даній статті.

Дотримання Великоднього посту для горян означає - очистити свою душу й тіло від набутих гріхів. Під час посту гуцули ідуть до церкви на сповідь та до причастя, (у гуцулів це ще зветься «іти до закону»).

На Бечкову неділю гуцули йшли до церкви за освяченою вербою. Гуцули вірили в те, що хто дістане розвиту бечку (регіональна назва верби), то буде для них і такий рік, веселий та косматий, як бечка. Хто урве з косматої бечки один пухнастий пупянок і проковтне його, то в того не буде боліти шия цілий рік. Бечка посвячена в вербну неділю мала цілющі властивості, нею виганяли худобу перший раз на пасовище, щоб добре велась [7, с. 229-230].

Проте, в його дослідженнях наведена інформація в цілому з Гуцульщини. Автор не наводить конкретного села з буковинської Гуцульщини, а тут варто зауважити, що обрядові дії, пов'язані з Вербною неділею мають певні відмінні риси в деяких гірських селах.

Так, у селі Стебні Путильського району побутує така традиція: коли господар чи господиня приносять освячену вербу додому, то першого, кого стріне в дома легенько б'є вербою, промовляючи три рази: «бечка б’є, я не б'ю, через тиждень Великдень», якщо когось із сім’і б’є, то потім обнімаються і бажають один одному здоров'я, пізніше господар обходить все господарство 3 таким ритуалом, спочатку з сім'єю, а потім із домашніми тваринами. Гуцули, таким чином, сповіщають радісну новину та вірять, що таке побиття принесе здоров’я їхній родині та господарству (с. Стебні, Скидан Василина Юрівна).

Звичай бити родичів освяченою вербою ще існував до християнства, мета такого звичаю полягала в розбудженні творчої енергії та в збереженні міцного здоров'я на цілий рік [2, с. 45-46].

Дослідниця Самотіс Я. описує цікавий ритуал 3 освяченою вербою в селах Берегомет Вижницького району, Розтоки, смт. Путила та с. Гробище Путильського району. Де освячену вербу, щоб захиститися від бурі та граду, кидали на поріг, або на двір, в смт. Путила та с. Гробище Путильського району для запобігання шкоди від бурі, палили в хаті гілки освяченої верби [6, с. 105].

Про походження назви «Вербна неділя» дослідник Кожолянко О. наводить таке припущення, що така назва походить від того, що іудеї зустрічали Христа гілками фінікової пальми на шостий день до його розп’яття. Про вербові котики описує таке: їх додавали до їжі дітей, щоб ті швидко росли, як верба, та мали силу сонячної весняної енергії. Тут же автор наводить різні прикмети, пов’язані з освяченими вербовими гілочками [3, с. 177]. 
Варто зазначити, що автор про вербну неділю не подає відомості з жодного села буковинської Гуцульщини, а подає загальні відомості про святкування обрядів у даному краї.

Тиждень перед Великоднем насичений великою кількістю різноманітних обрядових дій. Про чистий четвер перед Великоднем різні етнографи наводять такі відомості: І. Сеньків описує, що гуцули в страсний тиждень ходять до церкви із грубими свічками (громовицями), які потім використовуються, як оберіг від бур і хвороб [7, с. 230].

У селі Розтоки Путильського району існує традиція: в Чистий четвер іти до церкви святити свічки. Важливим моментом у даній обрядовій дії є: донести палаючі свічки до своєї оселі, щоб ті не згасли в дорозі (Різун Василь Георгійович, с. Розтоки).

Ще в страсний тиждень гуцули палили перед хатами вогні, це називалося «гріти діда», зазвичай, це робилося в Живний четвер, який ототожнювався із святом померлих [7, с. 230]. Один 3 цікавих звичаїв на Гуцульщині описує дослідник Кутельмах М., що в «чистий четвер» діти ходили під вікнами господарів і вигукували: «Грійте діда! Дайте хліба», господарі відповідали: «Гріємо, гріємо, даємо» та обдаровували дітей коржиками-кукуцами [4, с. 295].

Дослідник Кайндль Р. Ф. називає цей звичай «старого спалити», або (гіда палити) або (Юдаса палити), чи (кегетала палити). Деякі гуцули запалюють вогонь на плитах, біля яких ставлять у посудині воду й буханку хліба. Такий звичай має назву «старенький гріється» (гідек сегрієт) [1, с. 104].

У четвер, перед Великоднем, гуцули прокидаються вранці до зорі й, насамперед, вмивають обличчя, щоб чистим та здоровим були весь рік. Також на даний час на Гуцульщині гарно зберігся звичай запалювати вогні в Чистий четвер, тільки сама назва дещо трансформувалася, гуцули цей обряд тепер називають «діда гріда», цього дня, зазвичай, спалюють все сміття, що назбиралося за період зими та чистки саду. Зазвичай, таке вогнище гуцули палять на городі, залишаючи для цього клаптик не засадженої землі, на якій пізніше садять огірки або мак. Гуцули вірять, що чим більше буде полум'я від ватри, тим краще вони задобрять своїх предків та прогріють землю для веснування (с. Стебні, Скидан Василина Юрівна).

У Великодню п’ятницю священик править службу Божу, а після служби 3 церкви виносять «плащаницю», до якої помолитися приходять всі християнські гуцули. У цей день гуцули тримають строгий піст і нічого не їдять. Після церкви всі шанобливі господарі відвідують гробки, щоб прибрати на могилках у своїх родичів (с. Стебні, Скидан Василина Юрівна).

У суботу ввечері гуцули складають Великодній кошик (мабуть, ніде в Україні немає такого ситого кошика, як на Гуцульщині), гуцули наповнюють його вареними яйцями, сиром, бринзою, молодим часником, хріном, бужениною, ковбасою, бабкою (маленька Паска), та різними солодощами, випічкою, фруктами (с. Усть-Путила, Мометко Єлена Танасівна).

На Великдень уся сім'я іде 3 пишним кошиком, накритим вишитим образом Христа, до церкви, окремо в хустині несуть велику «Паску» та баночку 3 водою, щоб посвятити ії біля церкви. Також беруть миски, наповнені такою 
ж їжею, що й в кошику, і після освячення їх роздають бідним чи родичам за поману. Після посвячення «Паски», як і на Святвечір, першим, що вживають гуцули, це посвячену воду цього дня, а потім дають за «поману» мисочки з свяченою їжею родичам чи бідним і ідуть додому, буває деякі повертають на цвинтар до померлих родичів пригостити їх свяченим. Цілий день на Паску дзвонять дзвони, всі бажаючі б'ють у вербові дощечки, що висять на дереві біля церкви, це для щастя та здоров’я на цілий рік (с. Стебні, Скидан Василина Юрівна).

У Пасхальний день молодь влаштовує різноманітні забави, які ще називаються гаївки чи веснянки. Одну з таких цікавих забав описує дослідник Кожолянко О., яка називається «Нитки», суть гри полягає в тому, що хлопець і дівчина кладуть на лаву нитки, стають по два боки і з закритими очима витягують їх. Якщо вони взяли одну й ту ж нитку - значить вони пара і одразу ж цілуються (с. Довгопілля, Путильщина [3, с. 182 ].

Гуцульський дослідник Хоткевич Г. описує стародавню великодню забаву на Гуцульщині, яка називається «хаповина», ця гра полягає в тому, що хлопці стають у шеренгу, серед них $є$ один мисливець, він вибирає двох товаришів 3 натовпу, одного називає «сарною», а іншого - «хапаву». «Хапава» зображає собаку, яка ловить «сарну», козла. Хлопці утворюють своєрідний кордон, через який не пускають козла [8, с. 15].

Весняні гаївки, починаються, зазвичай, ще 3 Благовіщення (7 квітня) і тривають аж до Зелених свят. Сеньків пише, що хороводні танці - веснянки були віддавна поширені в народів Середземного моря, тільки там вони були пов'язані із культом богинь. Тут він наводить припущення, що грецькі хороводи могли мати вплив на наші гаївки. Однак в Гуцульських гаївках переважала аграрна тематика, та просто фліртуючи забави дівчат із хлопцями. Тут автор також наводить приклади деяких гаївок та описує їх суть [7, с. 234239]. Проте, автор не наводить інформації 3 жодного села буковинської Гуцульщини, а описує Гуцульщину в цілому, порівнюючи ії з ін. регіонами.

Про веснянки на Гуцульщині сьогодні мало зібраної інформації, особливо про стародавні веснянки. Дослідниця Я. Музиченко описує веснянку на Великдень, яка називається «біг наввипередки», гра полягає в тому, що гурт хлопців вибирає головного серед своїх, якого звуть «Береза», він відходить від хлопців на кілометр і подає команду бігти, хлопці в парі біжать, хто перший прибіжить, отримує «жезло», потім ця ж пара біжить назад, якщо перемагає знову ж той самий, то він отримує від свого компаньйона писанку, після парних перегонів кількість учасників збільшується. Парубка, який пробіг найкраще, гойдають юрбою на руках та вихваляють [5, с. 134].

На буковинській Гуцульщині особливу роль відіграє великодня писанка, яка $є$ як символ Христового Воскресіння. Проте, яйце в язичницькі часи на Гуцульщині було символом плодючої весни, зародженням життя. Дослідник Хоткевич Г. описує назви писанок на Гуцульщині поч. ХХ ст. Серед них такі назви: «смерічка», «шість руж», «гребінці», «плетінка», «білокрилка», «настулька», «решітки» [8, с. 13].

Традиційно, гуцули на паску обдаровують своїх родичів, друзів писанками, бажаючи при цьому один одному здоров’я. Яйця, які призначені 
для писанки, повинні бути сирими. І. Сеньків писав, що писанка була первісним символом дівочого ovum, а червона барва символом їхньої крові [7, с. 232].

Варто зазначити, що на буковинській Гуцульщині на даний час побутують і сирі, й варені, і навіть печені писанки, тут у певній мірі відбулася трансформація обряду, пов’язаного 3 писанками. Писанками обдаровують, зазвичай, тільки у Великодній день. Коли господарі дають за поману миски із свяченим, своїм кревним чи просто малозабезпеченим, то в цих мисках обов’язково має бути писанка (с. Стебні, Скидан Василина Юрівна).

3 польових досліджень у селі Бісків Путильського району Самотіс $Я$. подає матеріал, що в понеділок після Великодня, малі хлопчики ходили за писанками. Але дослідниця не описує, що казали ці діти господарям [6, с. 110].

Така ж традиція побутує й досі в с. Стебні Путильського району, діти ходять до християнських осель і кажуть: «Христос Воскрес, з святами вас, ми прийшли за писанками», обов'язково вінчують господарів: «нарік дочикати та гарні врожаї мати», інколи діти розповідають віршики у вигляді гуморесок (с. Стебні, Скидан Василина Юрівна).

Тиждень після Великодня на Гуцульщині вважається священним, цього тижня намагаються нічого не робити, що стосується різати, колоти, шити. Також гуцули вірять, що хто в цей тиждень помре, то зразу попаде до раю, бо брама до раю буде відкрита в ці дні (с. Стебні, Скидан Василина Юрівна).

Першу неділю після Пасхи українці називають по-різному: Провідна неділя, поминальна неділя, Томина неділя. На Гуцульщині найбільш прижита назва, гробки чи «Дідова субота».

На Дідову суботу гуцули влаштовують на гробках кревних трапези для живих i померлих родичів. Господині накривають гроби своїх родичів вишитими рушниками і на них кладуть різні наїдки, обов'язково приносять великодню паску та нарізають іiі замість хліба. Пізніше запрошують священика, щоб той освятив поминальні харчі та провів панахиду над гробом. Після таких обрядових дій священика, родичі покійників запрошують до трапези сусідів по гробках, друзів, жебраків та всіх, хто проходить мимо [7, с. 244 ].

Коли гуцули давали їжу з гробків за прости-біг комусь, то обов'язково казали за чию вони душу дають, називаючи ім'я померлих, та ким вони приходились їм. А ті, хто брали їжу мали відповідати «прости-біг, най Бог приймає» (с. Усть-Путила, Мометко Єлена Танасівна).

Наукова новизна полягає в тому, що вперше досліджені та зібранні матеріали про регіональні особливості пасхальних свят та обрядів у селах Стебні, Розтоки, Усть-Путила буковинської Гуцульщини. Дослідження яких дозволить відродити цілісну обрядову дію святкування українців від Вербної неділі до Провідної неділі, та надасть можливість знайти спільні та відмінні риси в святкуванні 3 іншими селами буковинської Гуцульщини. Осягнути їх первісну сутність та етапи розвитку.

Висновки: Аналізуючи та досліджуючи пасхальну обрядовість в селах Стебні, Розтоки, Усть-Путила Путильського району буковинської Гуцульщини було виявлено регіональні особливості в святкуванні великодніх свят притаманних тільки гуцулам буковинського краю. До головних особливостей, 
характерних на буковинській Гуцульщині належать: обрядова дія з вербою на Вербну неділю, ставлення гуцулів до вогню в чистий четвер, особливим вшануванням предків під час всього святкування великодніх свят та обрядові дії дітвори, які ходили за писанками в понеділок після Великодня.

\section{Список використаних джерел}

1. Кайндль Р. Ф. «Гуцули» : їх життя, звичаї та народні перекази / Р. Ф. Кайндль. - Чернівці : Молодий буковинець, 2000. - 208 с.

2. Килимник С. Український рік у народних звичаях в історичному освітленні / С. Килимник. - Вінніпег-Торонто, 1962. - 372 с.

3. Кожолянко О. Г. Календарні свята та обряди українців Буковини: семантика і символіка / О. Кожолянко ; Ін-т народознавства НАН України. - 2-е вид. Чернівці : Друк Арт, 2014. - 383 с.

4. Кутельмах К. М. Календарна обрядовість / К. М. Кутельмах // Гуцульщина: історико-етнографічне дослідження. - Київ, 1987. - С. 286-302.

5. Музиченко Я. Від Романа до Йордана: обряди, символи, страви / Я. Музиченко. - Львів : Свічадо, 2011 - 138 с.

6. Самотіс Я. Традиційна великодня обрядовість буковинських гуцулів Я. Самотіс // Народознавчі зошити. - 2014. - С. 103-113.

7. Сеньків I. Гуцульська спадщина : праці 3 життя i творчості гуцулів / I. Сеньків. - Чернівці-Верховина : Друк-Арт, 2014. - 512 с.

8. Хоткевич Г. Гуцули й Гуцульщина / Г. Хоткевич. - Б. м.: друк. «Свободи» 83. $-1920-32$ c.

\section{References}

1. Kaindl, R.F. (2000). Hutsuli: their life, customs and folk retellings. Chernivtsi: Molodyi bukovynets.

2. Kylymnyk, S. (1962). Ukrainian year in folk customs in historical light. VinnipehToronto.

3. Kozholianko, O.H. (2014). Calendar holidays and ceremonies of Ukrainian Bukovina: semantics and symbolism. Chernivtsi: Druk Art.

4. Kutelmakh. K.M. (1987). 'Kalendarna obriadovist'. Hutsulshchyna: Istorykoetnohrafichne doslidzhennia [Huzulschyna: historical and ethnographic research], pp. 286-302.

5. Muzychenko, Ya. (2011). From Roman to Jordan: rituals, symbols, dishes. Lviv : Svichado.

6. Samotis, Ya. (2014). Traditional Easter Rite of Bukovinian Hutsuls. Narodoznavchi zoshyty [Cognitive notebooks], pp. 103-113.

7. Senkiv, I. (2014). Hutsul Heritage: works on the life and work of Hutsuls. Chernivtsi-Verkhovyna : Druk-Art.

8. Khotkevych, H. (1920). Hutsuls and Hutsulshchyna. N.p. druk. «Svobody» 83.

(C) Козек M. I., 2018 